Vol. 1 No. 3 November 2021, e-ISSN : 2797-0140 | p-ISSN : 2797-0590

\title{
MENINGKATKAN HASIL BELAJAR SISWA PADA MATERI BAHASA INGGRIS MELALUI PEMBELAJARAN DENGAN PENGGUNAAN MEDIA AUDIO VISUAL DI KELAS 7 SEMESTER GENAP 2020/2021 SMPN 4 MATARAM
}

\author{
ANDI MASANI \\ SMPN 4 Mataram, Kec Cakranegara, Mataram \\ e-mail: andimasani15@gmail.com
}

\begin{abstract}
ABSTRAK
Penelitian ini bertujuan untuk mengetahui peningkatan hasil belajar peserta didik kelas SMPN 4 Mataram. Jenis penelitian ini adalah Penelitian Tindakan Kelas (PTK). Berdasarkan hasil penelitian, dapat disimpulkan bahwa penerapan penggunaan media audio visual dapat meningkatkan hasil belajar Bahasa Inggris peserta didik. Sebelum diterapkan penggunaan media audio visual pada siklus I nilai rata -rata kelas pada ranah kognitif 67,3 persentase ketuntasan 58,33\%. Pada siklus II hasil belajar peserta didik yaitu rata-rata kelas pada 77,3 dengan persentase ketuntasan $83,33 \%$. Pada siklus III hasil belajar peserta didik yaitu rata-rata kelas pada ranah kognitif 87,5 dengan persentase ketuntasan $100 \%$. Berdasarkan hasil penelitian dan pembahasan, serta analisis data yang telah diuraikan dapat disimpulkan bahwa pembelajaran penggunaan media audio visual dapat meningkatkan hasil belajar Bahasa Inggris kelas VII SMPN 4 Mataram pada Semester Genap Tahun Pelajaran 2020/2021.
\end{abstract}

Kata Kunci: Penggunaan Audio Visual, Media Pembelajaran, Hasil Belajar Siswa

\section{ABSTRACT}

This study aims to determine the improvement of student learning outcomes in the class of SMPN 4 Mataram. This type of research is Classroom Action Research (CAR). Based on the results of the study, it can be concluded that the application of the use of audio-visual media can improve students' Inggrisn learning outcomes. Before applying the use of audio-visual media in the first cycle, the average value of the class in the cognitive domain was 67.3, the percentage of completeness was $58.33 \%$. In the second cycle, the students' learning outcomes were the average class at 77.3 with a completeness percentage of $83.33 \%$. In cycle III the learning outcomes of students are the average class in the cognitive domain of 87.5 with a $100 \%$ completeness percentage. Based on the results of the research and discussion, as well as the analysis of the data that has been described, it can be concluded that learning the use of audiovisual media can improve learning outcomes of Indonesian class VII SMPN 4 Mataram in the Even Semester of the 2020/2021 Academic Year.

Keywords: Use of Audio Visual, Learning Media, Student Learning Outcomes

\section{PENDAHULUAN}

Menurut Keraf dalam Smarafradiba (2005:1) menyatakan bahwa sebagai alat komunikasi antar anggota masyarakat berupa symbol bunyi yang dihasilkan oleh alat ucap manusia. Belajar bahasa pada hakikatnya adalah belajar berkomunikasi oleh karena itu pembelajaran bahasa diarahkan untuk meningkatkan kemampuan pembelajar untuk berkomunikasi baik lisan maupun tulis, (Depdikbud, 1995). Bahasa Inggris adalah bahasa yang digunakan oleh warga Inggris dan sebagai bahasa persatuan antar warga.

Pembelajaran Bahasa Inggris merupakan salah satu materi pembelajaran yang sangat penting di sekolah. Tujuan pembelajaran Bahasa Inggris adalah agar siswa memiliki kemampuan berbahasa Inggris yang baik dan benar serta dapat menghayati bahasa dan sastra Inggris sesuai dengan situasi dan tujuan berbahasa serta tingkat pengalaman siswa sekolah menengah (Akhadiah dkk. 1991:1).

Tujuan pembelajaran Bahasa Inggris adalah untuk mengembangkan kemampuan berbahasa Inggris sesuai dengan kemampuan, kebutuhan, dan minatnya sedangkan bagi guru adalah untuk mengembangkan potensi Bahasa Inggris serta lebih mandiri dalam menentukan 
bahan ajar kebahasaan sesuai dengan kondisi lingkungan sekolah dan kemampuan siswa (BSNP.2006).

Tujuan umum pembelajaran sebuah bahasa adalah memiliki peran sentral dalam perkembangan intelektual, social, emosional peserta didik dan merupakan penunjang keberhasilan dalam mempelajari semua bidang studi. Dengan pembelajaran bahasa memngkinkan manusia saling berkomunikasi, saling berbagi pengalaman, saling belajar dari yang lain untuk meningkatkan manusia meningkatkan kemampuan intelektual.

Pejalajaran Bahasa Inggris diharapkan untuk meningkat kemampuan peserta didik untuk berkomunikasi dalam Bahasa Inggris dengan baik dan benar, baik secara lisan maupun tulis, serta menumbuhkan apresiasi terhadap hasil karya kesastraan manusia Inggris. Dengan pembelajaran Bahasa Inggris siswa di harapkan memiliki kemampuan sebagai berikut:

1. Siswa di harapkan mampu menggunakan Bahasa Inggris secara baik dan benar serta dapat berkomunikasi secara efektif dan efisien secara lisan mampu tulis sesuai dengan etika yang berlaku.

2. Siswa bangga dengan menghargai Bahasa Inggris sebagai bahasa Negara dan bahasa persatun bangsa Inggris.

3. Siswa mampu memahami Bahasa Inggris serta dapat menggunakannya dengan tepat dan kreatif untuk berbagai tujuan.

4. Siswa mampu menggunakan Bahasa Inggris untuk meningkatkan kemampuan intelektual serta kematangan emosional dan sosial.

Dengan mengetahui fungsi Bahasa Inggris, tentu kita akan selalu berusaha untuk mempelajari dan menguasai Bahasa Inggris dengan sungguh- sungguh. Sebab dengan demikian secara tidak langsung kita telah berusaha untuk membina persatuan dan kesatuan bangsa, serta melestarikan budaya bangsa.

Kata media berasal dari bahasa Latin medius yang secara harfiah berarti tengah, perantara atau pengantar. Dalam bahasa arab media adalah perantara atau pengantar pesan dari pengirim kepada penerima pesan. Menurut Gerlach dan Ely (dalam Arsyad, 2011: 3) mengatakan bahwa media apabila dipahami secara garis besar adalah manusia, materi atau sikap. Dalam pengertian ini guru, buku teks, dan lingkungan sekolah merupakan media. Secara lebih khusus, pengertian media dalam proses belajar mengajar cenderung diartikan sebagai alatalat grafis, photografis, atau elektronis, untuk menangkap, memproses dan menyusun kembali informasi visual atau verbal.

Secara sederhana istilah media dapat didefinisikan sebagai perantara atau pengantar. Sedangkan istilah pembelajaran adalah kondisi untuk membuat seseorang melakukan kegiatan belajar. Dengan merujuk pada devinisi tersebut maka media pembelajaran adalah wahana penyalur pesan atau informasi belajar sehingga mengkondisikan seseorang untuk belajar atau berbagai jenis sumber daya yang dapat difungsikan dalam proses pembelajaran, berdasarkan ruang lingkup sumber belajar di atas, maka media pembelajaran merupakan bagian dari sumber belajar yang menekankan pada software atau perangkat lunak dan hardware atau perangkat keras.

Rossi dan Breidle (Sanjaya, 2008: 204) mengemukakan bahwa media pembelajaran adalah seluruh alat dan bahan yang dapat dipakai untuk mencapai tujuan pendidikan seperti radio, televisi, buku, koran, majalah, dan sebagainya. Menurut Rossi alat-alat semacam radio dan televisi kalau digunakan dan diprogram untuk pendidikan maka merupakan media pembelajaran.

Menurut Education Association (NEA) mendefenisikan sebagai benda yang dapat dimanipulasikan, dilihat, didengar, dibaca atau dibicarakan beserta instrumen yang dipergunakan dengan baik dalam kegiatan belajar mengajar, dapat dipengaruhi efektifitas program instruksional. Sedangkan menurut Association of Education and Communication Technology (AECT) media adalah segala bentuk dan saluran yang digunakan untuk menyalurkan pesan atau informasi. 
Selain pengertian di atas, ada juga yang berpendapat bahwa media pengajaran meliputi perangkat keras (hardware) dan perangkat lunak (software). Hardware adalah alat-alat yang dapat mengantarkan pesan seperti overhead projector, radio, televisi, dan sebagainya. Sedangkan software adalah isi program yang mengandung pesan seperti informasi yang terdapat transparasi atau buku dan bahan-bahan cetakan lainnya, cerita yang terkandung dalam film atau meteri yang disuguhkan dalam bentuk bagan, grafik, diagram dan lain sebagainya.

Media audio visual adalah media instruksional modern yang sesuai dengan kemajuan ilmu pengetahuan dan teknologi, meliputi media yang dapat dilihat, didengar dan yang dapat dilihat dan didengar. Media audio visual adalah jenis media yang selain mengandung unsur suara juga mengandung unsur gambar yang bisa dilihat. Misalnya rekaman video, berbagai rekaman film, slide suara, dan lain sebagainya. Kemampuan media ini dianggap lebih baik dan lebih menarik. Penekanan utama dalam pengajaran audio visual adalah pada nilai belajar yang diperoleh melalui pengalaman konkret, tidak hanya didasarkan atas kata-kata belaka.

Media audio visual menurut Encyclopedia of Educational Research memiliki nilai atau manfaat sebagai berikut:

1. Meletakkan dasar-dasar yang kongkret untuk berpiki. Oleh karena itu mengurangi verbalisme (tahu istilah tetapi tidak tahu arti, tahu nama tetapi tidak tahu bendanya).

2. Memperbesar perhatian siswa.

3. Membuat pelajaran lebih menetap atau tidak mudah dilupakan.

4. Memberikan pengalaman yang nyata yang dapat menumbuhkan kegiatan berusaha sendiri di kalangan para siswa.

5. Menumbuhkan pemikiran yang teratur dan kontinu.

6. Membantu tumbuhnya pengertian dan membantu perkembangan kemampuan berbahasa.

Manfaat selain yang tersebut di atas adalah:

1. Sangat menarik minat siswa dalam belajar.

2. Mendorong anak untuk bertanya dan berdiskusi karena ia ingin mengetahui lebih banyak.

3. Menghemat waktu belajar. Guru tidak usah menerangkan sesuatu dengan banyak perkataan, tetapi dengan memperlihatkan suatu gambar, benda yang sebenarnya atau alat lain.

Belajar adalah suatu kata yang sering didengar oleh semua lapisan masyarakat. Bagi para pelajar kata "belajar" merupakan kata yang tidak asing bahkan merupakan bagian yang tidak terpisahkan dari semua kegiatan mereka dalam menuntut ilmu diberbagai lembaga pendidikan formal. Kegiatan belajar mereka lakukan setiap waktu sesuai dengan keinginan, baik pada malam hari maupun pagi hari.

Kegiatan belajar merupakan suatu kegiatan yang paling pokok dari keseluruhan proses belajar disekolah. Ini berarti berhasil atau tidaknya pencapaian tujuan pendidikan banyak bergantung pada bagaimana proses belajar yang dialami sisiwa sebagai anak didik disekolah. Para pakar pendidikan mengemukakan pengertian yang berbeda dalam belajar, namun selalu mengacu pada prinsip yang sama yaitu setiap orang yang melakukan proses belajar akan mengalami suatu perubahan dalam dirinya. Menurut (Hamalik, 2001 : 27) "Belajar merupakan suatu proses, suatu kegiatan dan bukan suatu hasil atau tujuan. Belajar bukan hanya mengingat, akan tetapi lebih luas dari itu, yakni mengalami". Hasil belajar bukan suatu penguasaan hasil latihan melainkan pengubahan kelakuan individu melalui interaksi dengan lingkungan.

Namun, dari dari semua itu tidak semua orang mengetahui apa itu belajar. Sebenarnya kata "Belajar" memiliki pengertian yang tersimpan didalamnya. Pengertian dari kata "Belajar" itulah yang perlu diketahui dan dihayati sehingga tidak menimbulkan pemahaman yang keliru mengenai masalah belajar. Menurut (Sadirman, 2004 : 34) "Belajar adalah suatu proses perubahan pengetahuan, pemahaman sikap, tingkah laku, keterampilan dan sebagainya".

Dalam hal ini Wijaya (2000 : 54) mengatakan: Belajar dalam arti luas adalah suatu proses perubahan tingkah laku yang dinyatakan dalam bentuk penguasaan bahan yang 
diajarkan, penilaian sikap, pengetahuan, dan percakapan dasar yang terdapat dalam berbagai bidang atau berbagai aspek kehidupan. Proses berarti interaksi antara individu dengan suatu sikap, nilai atau kebiasaan, pengetahuan, dan keterampilan dalam hubungan dengan dunianya sehingga ia berubah.

Berdasarkan definisi belajar yang dikemukakan para ahli diatas, maka dapat disintesiskan bahwa belajar adalah perubahan serta peningkatan kualitas dan kualitas tingkah laku seseorang diberbagai bidang yang terjadi akibat melakukan interaksi terus menerus dengan lingkungannya. Peningkatan kualitas dan kuantitas tersebut dapat dilaksanakan melalui pembelajaran terutama di sekolah-sekolah.

Hasil belajar adalah perubahan yang terjadi dalam diri seseorang berlangsung secara berkesinambungan, tidak statis (Slameto. 2010: 3). Dalam Kamus Besar Bahasa Inggris (2003 : 729 ) menyebutkan belajar adalah berusaha memperoleh kepandaiaan atau ilmu tertentu dengan tergantung pada kekuatan harapan bahwa tindakan tersebut akan diikuti oleh suatu hasil tertentu dan pada daya tarik hasil itu bagi orang bersangkutan.

Menurut Sudjana (2005: 12) hasil belajar adalah hasil yang dicapai oleh siswa yang telah mengikuti proses belajar mengajar. Hasil pada dasarnya merupakan sesuatu yang diperoleh dari suatu aktifitas, sedangkan belajar merupakan suatu proses yang mengakibatkan perubahan pada individu, yakni perubahan tingkah laku, baik aspek pengetahuannya, keterampilannya, maupun aspek sikapnya. Hasil belajar merupakan istilah yang digunakan untuk menunjukkkan tingkat keberhasilan yang dicapai oleh seseorang setelah melakukan usaha tertentu. Dalam hal ini hasil belajar yang dicapai siswa dalam bidang studi tertentu setelah mengikuti proses belajar mengajar. Sedangkan menurut Horwart Kingsley dalam Sudjana (2005: 23) membagi tiga macam hasil belajar mengajar: (1). Keterampilan dan kebiasaan, (2). Pengetahuan dan pengarahan, (3). Sikap dan cita-cita.

Salah satu mata pelajaran yang menunjukkan hasil belum maksimal adalah mata pelajaran Bahasa Inggris di SMPN 4 Mataram. Pencapaian nilai rata-rata mata pelajaran Bahasa Inggris masih berada di bawah nilai rata-rata. Kondisi ini disebabkan oleh berbagai faktor. Salah satunya disebabkan karena masih rendahnya motivasi dalam diri siswa. Rendahnya motivasi ini salahsatunya dipicu oleh kurang menariknya proses belajar mengajar. Sebagian besar guru masih sering menggunakan metode konvensional dan lebih banyak berpusat pada guru. Lebih kurang $90 \%$ guru masih menggunakan metode ceramah atau tanya jawab dan jarang dibantu dengan media pembelajaran. Para guru lebih banyak menguasai kelas dan jarang memberi kelonggaran siswa untuk berinisiatif.

Model pembelajaran yang diterapkan di SMPN 4 Mataram lebih banyak menggunakan metode konvensional yang menjadikan peserta didik kurang tertarik dengan materi yang disampaikan guru. Apalagi jika guru bukan pembicara yang baik, artinya guru tidak dapat menyampaikan dengan cara yang menyenangkan. Kondisi semacam ini menyebabkan siswa kurang berminat terhadap mata pelajaran. Kurangnya minat dan motivasi siswa dalam pembelajaran akan berdampak pada jalannyaproses pembelajaran. Untuk itu, sudah waktunya guru memperbaiki proses pembelajaran yang dapat membangkitkan semangat peserta didik agar mereka senang dan bergairah mengikuti pembelajaran di kelas. Terkait dengan permasalahan ini, maka dicoba satu alternatif yakni pembelajaran dengan penggunaan media audiovisual.

Berdasarkan pemikiran di atas, maka disusun Penelitian Tindakan Kelas dengan judul "Meningkatkan Hasil Belajar Siswa Materi Bahasa Inggris Melalui Pembelajaran dengan Penggunaan Media Audio visual SMPN 4 Mataram"

\section{METODE PENELITIAN}

Penelitian ini adalah Penelitian Tindakan Kelas (PTK) atau Classroom Action Research (CAR), yakni penelitian untuk mencari pemecahan praktis terhadap permasalahan faktual bersifat lokal yang terjadi di kelas tempat peneliti sendiri. Penelitian ini dilaksanakan di SMPN 
4 Mataram. Penelitian tindakan kelas ini dilaksanakan di kelas VII pada semester 1 tahun pelajaran 2020/2021.

Kegiatan penelitian ini dilakukan melalui beberapa prosedur atau tahapan sebagai berikut, 1) persiapan, 2) pengenalan awal, 3) penyusunan rencana tindakan, 4) pelaksanaan atau implementasi tindakan, 5) pengamatan, dan 6) refleksi. Rencana tindakan dalam penelitian ini berupa pembuatan siklus-siklus yang setiap siklusnya memuat beberapa langkah dalam menyelesaikan satu permasalahan. Dalam hal ini ada tiga siklus tindakan yakni fase persiapan, fase kedua pengumpulan data, ketiga analisis dan keempat penyusunan laporan.

\section{HASIL DAN PEMBAHASAN}

Berdasarkan hasil pengamatan dan wawancara dengan guru Bahasa Inggris dapat disampaikan bahwa kelas VII SMPN 4 Mataram termasuk kelas dengan siswanya memiliki hasil belajar rendah dibandingkan dengan kelas lainnya. Selain itu para siswa kurang begitu memahami tentang penggunaan media audio visual. Dari hasil wawancara penulis dengan para siswa, diketahui bahwa para guru belum secara maksimal menggunakan media audio visual sebagai salah satu strategi dalam pembelajaran. Hal ini menyebabkan kurangnya motivasi siswa untuk mengikuti pelajaran yang pada akhirnya berdampak pada rendahnya hasil belajar. Penelitian ini dilaksanakan melalui siklus yang berkelanjutan, serta direncanakan dengan melaksanakan siklus-siklus. Penelitian tindakan ini dilaksanakan dari bulan September 2020 sampai dengan bulan Februari 2021 dengan melalui tiga siklus. Pada setiap pemberian tindakan berupa proses pembelajaran dengan menggunakan media audio visual dengan mengaplikasikan tiga model pembelajaran yang terangkum dalam tiga siklus. Berikut ini dikemukakan deskripsi penelitian tiap-tiap siklus.

\section{a. Siklus I}

Pelaksanaan siklus I terdiri dari lima tahap kegiatan yaitu ide awal, temuan dan analisis, perencanaan umum, langkah tindakan, pengamatan dan evaluasi. Hasil belajar Bahasa Inggris sebelum dilaksanakan tindakan pada siklus I masih di bawah Kriteria Ketuntasan Minimal (KKM) yang ditetapkan yaitu 75. Peserta didik yang tuntas $58,33 \%$, sedang yang belum tuntas 41,67\%. Dari data hasil belajar tersebut menggambarkan bahwa mata pelajaran bahasaInggris di kelas VII SMPN 4 Mataram masih banyak yang belum tuntas.

\section{b. Siklus II}

Pelaksanaan Pembelajaran yang dibuat bersama dengan peneliti. Pelaksanaan tindakan siklus II adalah tindakan proses pembelajaran dengan menggunakan media audio berupa tape recorder. Observasi atau pengamatan dilakukan oleh teman sejawat maupun oleh peneliti sendiri. Pengamatan ini dilakukan dengan menggunakan lembar observasi terhadap proses pembelajaran yang dilakukan oleh guru model dan siswa selama dua jam pelajaran.Berdasarkan hasil pengkajian dapat dikemukakan secara umum dari sisi kinerja guru cukup baik. Berdasar evaluasi proses pembelajaran pada siklus II ini, peneliti melakukan analisis dan refleksi sebagai berikut:

1) Dalam proses pembelajaran Bahasa Inggris perlu membiasakan dengan memanfaatkan media pembelajaran yang menarik sehingga siswa lebih termotivasi dan tidak jenuh,

2) Guru perlu membangkitkan minat belajar peserta didik agar para siswa dapat mengikuti proses pembelajaran dengan baik. Siswa yang aktif diberi pujian dan siswa yang pasif ditegur,

3) Guru perlu memberikan contoh cara-cara menyampaikan pendapat yang baik dan benar,

4) Peneliti perlu melakukan sharing dengan guru Bahasa Inggris lain, bagaimana cara meningkatkan hasilbelajar.

Diskusi di ruang guru SMPN 4 Mataram. Dalam diskusi itu, peneliti menyampaikan hasil pengamatan pembelajaran di kelas VII. Peneliti dan guru menyepakati tentang upaya peningkatan hasil belajar siswa serta pentingnya penggunaan media audio visual. Peneliti dan 
guru membuat RPP dan berusaha memperbaiki kekurangan dalam pembelajaran pada siklus II. Dalam diskusi ini difokuskan pada pemanfaatan media pembelajaran audio visual berupa Laptop dan LCD. Dalam hal ini cara memilih berita diusahakan setepat mungkin dan sesuai dengan taraf perkembangan anak.

\section{c. Siklus III}

Guru model melaksanakan proses pembelajaran sesuai dengan RPP yang telah dibuat. Pukul 07.00 guru membuka pelajaran dengan mengabsen anak. Selesai mengabsen guru meminta anak untuk duduk berkelompok dengan anggota enam anak dalam satu kelompok. Guru memberi tugas yang harus dikerjakan oleh kelompok dan menginformasikan bahwa setiap kelompok harus mempresentasikan hasil kerjaannya. Dari hasil pengamatan selama proses pembelajaran pada siklus III peserta didik lebih kondusif dibandingkan dengan siklus II. Siswa lebih bersemangat, aktif, dan terjadi interaksi yang sangat bagus dengan guru model. Ini terlihat saat mengerjakan latihan dalam diskusi kelompok, mereka aktif membahas soal secara bersama-sama. Setiap anggota kelompok berpartisipasi aktif ikut memberikan pendapatnya untuk menyelesaikan tugas. Tentang kondisi kemampuan awal dijelaskan bahwa SMPN 4 Mataram merupakan sekolah terakreditasi dengan nilai B.

Peningkatan hasil belajar Bahasa Inggris setelah menggunakan media pembelajaran tape recorder, laptop, dan LCD, dijelaskan bahwa pada deskripsi hasil penelitian tentang peningkatan hasil belajar Bahasa Inggris, pembahasan dilakukan terhadap hasil ulangan dan pengaruh penggunaan media audio visual terhadap hasil belajar siswa kelas VII SMPN 4 Mataram. Pada siklus I (Sebelum tindakan) peserta didik yang tuntas sebanyak 21 siswa $(58,33 \%)$ dan yang belum tuntas sebanyak 15 (41,37\%). Pada siklus II (setelah tindakan) yang tuntas 30 siswa $(83,33 \%)$ yang belum tuntas sebanyak 6 siswa $(16,67 \%)$. Pada siklus III semua siswa sebanyak 36 tuntas (100\%). Jadi hasil belajar Bahasa Inggris setelah dilakukan tindakan ada peningkatan. Inovasi model pembelajaran dengan menggunakan media elektronika menuntut keterampilan guru dalam menentukan media mana yang dapat menarik minat siswa sehingga kegiatan pembelajaran berjalan efektif. Setiap guru harus menyiapkan media yang akan dipergunakan dalam proses pembelajaran.

\section{KESIMPULAN}

Berdasarkan hasil penelitian yang didapat diatas, dapat ditarik simpulan hasil penelitian sebagai berikut. Dari hasil pengamatan peneliti, ternyata kegiatan pembelajaran yang dilakukan oleh guru Bahasa Inggris kurang bervariasi. Hasil belajar Bahasa Inggris sebelum dilaksanakan tindakan pada siklus I masih di bawah Kriteria Ketuntasan Minimal (KKM) yang ditetapkan yaitu 75. Berdasarkan hasil pengkajian dapat dikemukakan secara umumdari sisi kinerja guru cukup baik.Dengan memperhatikan kelemahan-kelemahan yang ada dalam pembelajaran, peneliti dan guru melakukan sharing ideas tentang beberapa hal berikut (1) Dalam proses pembelajaran Bahasa Inggris perlu menggunakan media pembelajaran elektronika. Dengan menggunakan media audio-visual ini diharapkan dapat mengurangi verbalisme dan kejenuhan siswa, (2) Guru perlu membangkitkan hasilbelajar peserta didik, (3) Guru menyusun RPP dengan pendekatan Contextual Teaching and Learning (CTL), (4) Guru menyusun instrumen soal dan format penilaian, (5) Diperbanyak latihan dan pembahasan soal.

Ada beberapa hal yang masih perlu diperbaiki pada pembelajaran di siklus III, yakni (1) kemampuan berbicara nahasa Inggris siswa masih kurang, (2) guru kurang aktif memberikan reinforcement (penguatan) kepada siswa yang menyampaikan pendapat secara baik dan benar. Sejumlah implikasi penting terhadap upaya peningkatan hasil belajar pada siswa kelas VII SMPN 4 Mataram. Implikasi tersebut dapat diuraikan sebagai berikut : (1) pembelajaran dengan strategi penggunaan media audio visual hendaknya dikembangkan dan dilaksanakan, (2) mengoptimalkan penggunaan media pembelajaran, maka pada setiap proses pembelajaran para siswa harus diberi kesempatan yang sebanyak- banyaknya untuk senantiasa memanfaatkan media pembelajaran yang ada disekolah. 


\section{DAFTAR PUSTAKA}

Arjanggi, R \& Suprihatin, T. (2010). Metode Pembelajaran Tutor Teman Sebaya Meningkatkan Hasil Belajar Berdasar Regulasi-Diri. Jurnal Makara, Sosial Humaniora, 14 (2), 9197.

Effendi, E. \& Zhuang, H. (2005). E-learning, Konsep dan Aplikasi. Yogyakarta: AndiOffset.

Graf, S. and List, B. (2005). An Evaluation of Open Source E-Learning Platforms Stressing Adaptation Issues. Vienna: University of Technology

Hulukati, W. (2011). Pengembangan Model Bahan Belajar Mandiri Berbasis Andragogi untuk Meningkatkan Kompetensi Pendidik Anak Usia Dini. Jurnal Penelitian dan Pendidikan, 8 (1),28-41.

Joyoatmojo, S. (2011). Pembelajaran Efektif, Pembelajaran yang Membelajarkan. Surakarta: Universitas Sebelas Maret Press.

Karagiorgi, Y. \& Symeou, L. (2005). Translating Constructivism into Instructional Design: Potential and Limitations. Journal of Educational Technology \& Society, 8 (1), 17-27.

Mawardi. (2011). Alumni's competences and user satisfaction of Primary Teacher Training Departmen, Faculty of Teacher Training and Education-Satya Wacana Christian University. Jurnal Ilmiah Pendidikan ke-SD-an SCHOLARIA. 1(2)60-87.

Mudjiman, H. (2011). Belajar Mandiri: Pembekalan dan Penerapan. Surakarta: Universitas Sebelas Maret Press.

Narmoatmojo, W. (2011). Implementasi Pancasila melalui Pendidikan Kewarganegaraan di Indonesia. Prosiding seminar Internasional di Malaysia pada tanggal 15 Januari 2012.

Nodoushan, M.,A.,S. (2012). Self-regulated learning (SRL): Emergence of the revised of SRL model (RSLRM). International Journal of Language Studies (IJLS),6(3), 1 -15. 